\title{
Research on Social Value of Managing University by Law
}

\author{
JiaNing. Zheng \\ China University of Political Science and Law \\ Beijing, China
}

\begin{abstract}
Managing university by law and creating awell-regulated school is a concrete manifestation of rule of law in the field of higher education, not only a school governance strategy chosen by the new era, but also the imperative request to deepen the reform of higher education and promote the development of higher education.Managing university by law has a beneficial effect on the improvement of the overall national strength, the realization of modern doctrine of rule oflaw and the construction of harmonious campus, which is of very considerable significance to ensure scientific and order management of higher education in China.
\end{abstract}

Keywords-managing university by law; harmonious university; social value

\section{OVERVIEW OF MANAGING UNIVERSITY BY LAW}

Managing university by law refers to a situation that all educational and teaching activities of universities shall be within the scope of statutory responsibilities and authorities, such as putting the teaching management and school activities into the orbit of the rule of law,taking into accountright claims andprotectionof rights and interests of various school subjects in the legal framework. "Law" refers to legislation of school management and "managing" refers toschool governance; in short managing university by law is to build a unification of educating people by law, management by law and services by law.Managing university by law is the embodiment of the principle of rule of law stipulated by the Constitution Law in the field of school education and management activities. Several Opinions on Strengthening the Work of Managing University by Law promulgated by Ministry of Education in 2003 points out that, managing school by law means keeping in strict accordance with the principles and provisions of the educational laws, carrying out educational and teaching activities, respecting students' dignity and safeguarding their legitimate rights and interests, to create an educational environment that meets the request of rule of law, to improve the law quality of school administrators and teacherscontinuously and to increase the capacity of school to deal with all kinds of relations by law.

Managing university by law is the embodiment of strategy of rule of law in the field of education. As the most basic educational entity, university is burdened with the important task of teaching and educatinghigh quality cultured students. The modern universities are of open and independent natures, with complex internal and external relations.It relies on the reasonable definition and regulation of the law and policy to coordinate the right and obligation relations between educational administrative departments and schools, between schools and teachers andbetween a student and another.The key of managing university by law is to impose procedural and substantiverestrictions on educational and teaching activities in accordance with the administrative lawsto achieve the requirements of rationalization of such activities.In recent years, People's Republic of China has promulgated a series of laws and regulations, such as Education Law of the People's Republic of China,Higher Education Law of the People's Republic of China, Regulations of the People's Republic of China on Academic Degrees and Provisions on the Administration of Students in Regular Institutions of Higher Education and promoted the activity of one university one charter in the whole country, sparing no effort to form the fundamental basis for managing university by law.

\section{VALUE OF IMPROVING THE COMPREHENSIVE NATIONAL POWER}

Higher Education is the main way of national education. Scientific and legal level in school management has a direct impact on the quality of university education, which has an effect on the quality of the overall people and a country's comprehensive national power.Take Japan for an example. While developing education and increasing investment in education,Japan made the complete School Education Law.By the way of rule of law to manage school and developschool education, regardingschool educationas the main channel toimproves the science, technology and culture quality of people, thus as a consequence, contributing to the rapid development of social productivity and to increasing Japan's comprehensive national power. From the year 1950 to 1972, the contribution rate of science education in national economic development rose up to $52 \%$. Then take the United States for an example. In 1862, Morrill Act was promulgated, which benefited the development of agriculture and engineering education in American higher education and stimulated the development of comprehensive university; then , in 1958, NationalDefenseEducationAct came into effect which strengthened science education and teacher trainingin US university and meanwhile developed science and technology, postgraduate education and research institution.

Law has become a kind of management strength to promote the healthy development of higher education. Recently, many universities in Chinaare busy expanding their school size, establishing University City and teaching bases and exploring subsidiary management system, like colleges or 
centers, and other new management models. During the innovation and reform, it is particularly urgent to strengthen the construction of university rules and regulations to manage university by law. Otherwise it will inevitably have an adverse effect on the smooth transition which further has an impact on enhancement of overall higher education quality. University should organize educational activities in the framework of laws and regulations, clarify relationships between the university and the government, regard the country's development strategic approach as their own goals and should be contributed to bringing up students developed in comprehensiveaspects as moral, intellect, physical fitness, etc., which could satisfy the social requirements in modern China.

\section{VALUE OF CONFORMING TO MODERN DOCTRINE OF RULE OF LAW}

The right to education is a fundamental constitutional right of citizens. With the knowledge economy coming, the right to education becomes a basis for citizens to enjoy other rights.Lack of theright to education will give rise to restriction and deprivation of the right to labor and furthermore will affect the achievement of other property rights of citizens. Lack of education will affect people's use of modern technologies to communicate, leading to the incomplete implementation of citizens' right to free expression. The defect of the right to education will reduce the social evaluation of the educated, resulting in a negative impact on citizens' right to reputation and right to honor. Therefore, it is obvious that, for the citizens, the right to education is that a slight move in one part may affect the whole situation.The education of universityhas a life-long and far-reaching influence on the right to education of citizens. Hence, it is the proper meaning of modern doctrine of rule oflaw to abandon the traditional theory of special power for immunity andinclude the management of higher education into the scope of rulingby law. Theory of special power for immunity is the main embodiment of the idea that the special power relationship is not under the regulation of the law. When specified in the field of university management, it refers to the unrestricted discretion power, exercised by universities to students, which is in a condition that it is totally exempted from judicial review, no matter whether or not the procedure is fare or the consequence is just.

For a long time, there are plenty of contradictions between Chinese traditional education ideasand contemporary thoughts of rule oflaw. On one hand, the reason why the legal rights and interests of the educated fail to get effective judicial protection is that the educated basically would not like to bring a lawsuit to the court concerning unreasonable management of university, due to the restriction of traditional ideas. On the other hand, because ofthe lack of relevant legislative provisions, lots of judges who are not expert on education actively enter into the field of higher education and thus it poses a serious challenge to the right to self-management of university in China.In order to resolve these contradictions, this paper hold the view that, from the perspective of school administrators,they should take the initiative to meet the requirements of moderndoctrine of rule oflaw and follow said principles andideas to carry out various educational management activities, and to prevent abuse of discretion in educational and teaching activities.

\section{VALUE OF PROTECTING THE HARMONIOUS UNIVERSITY}

With the development of the socialist market economy and joining into the WTO, the idea of rule oflaw continues to deepen. Especially, the young generation's thought pattern has also undergone fundamental change. As the paceson rule oflaw accelerated in China, parents'and students' consciousand knowledgeof law haverapidly rose. Therefore, university management faces quantities of challenges than before, such as rigid administrative management, pressure of employment rate, tense relationship between students and teachers, and so on. As the saying goes, channels for knowledge to transfer are widening while doors for emotional communication are narrowing. These phenomenon lead discordant affairs happened in the campus of university.

In view of this paper, the core to solve this problems is by the way ofmaking school chapterand regulations in the university education and teaching activities, in order to improve the internal and external relations in the university administration and establish an effective mechanism for balancing measure.Implementation of managing university by law means the change of ideas,through multi-channels and multi-forms tocarry out publicity activities regarding rule of law, arming the mind of staff and students with good awareness of law, so as to make it a conscious behavior and habit to comply with the law, pay respect for the law and perform actions in accordance with the law.Managing university by law refers to full implement of policies concerning educationstrategy of the nation, strict accordance with the principles and provisions of educational legislation, organizingeducational activities,showing respect for personalities of teachers and students and safeguarding the legitimate rights and interests of all parties so thatschool's capacity to deal with all kinds of relations by law could be increased.Implementation of managing university by law is to constantly improve the democratic management of school system and realizethe management and operation of school provisions, standards and procedures, toformthe pattern that the educational administrative authorities perform the administrative power according to the law and meanwhile,the university manages its own business independentlyby law and shall be under supervision.

In summary, there is a long way to go to manage university by law. To achieve the ultimate goal,we shallbe in compliance with lawprovisions seriously and governschool affairs strictly in accordance with its regulations, in order toensure the correct direction of higher education to its very foundations and make higher education policy to be fully implemented.Managing school by law aims to create a teaching and learning situation that is orderly and harmonious, by the way of preventing disputes and incidents by the power of laws, school chapters and regulations, resolving contradictions and conflicts constantly, integratingcampus resources, maintainingcampus order and eliminating uncertain factors on campus in civilized and rational manners. 


\section{ACKNOWLEDGEMENT}

Zheng Jianing, Associate Professor of China University of Political Science and Law. This paper is supported by Program for Young Innovative Research Team in China University of Political Science and Law (Program Number: 2014CXTD05).

\section{REFERENCE}

[1] Xu Zhiqing: "Recognition on the Practice of Managing University by Law”, Journal of ShanXi Finance and Economics University, April 2012, p.256.

[2] See Outline for Promoting Managing School by Law in an All-round Way, promulgated by Ministry of Education in 2013.

[3] See Outline for Promoting Managing School by Law in an All-round Way, promulgated by Ministry of Education in 2013.

[4] See Yin Yan: On the Necessity of Administrating Universities by Law, Journal of Southwest Agricultural University (Social Science Edition), March 2005, and p.114.

[5] See Wu Peng: "Special Power Relationship Theory and the Administrative Lawsuit of the Right to Education”, Journal of Chinese Academy of Governance, $20113^{\text {rd }}$ Edition, pp.72-76.

[6] Li Xianguang: “On Feasibility of Strategy of Managing University by Law”, People’s Tribune, August 2011, p.134. 